\title{
РОЛЬ МОТИВАЦІЇ У ПРОЦЕСІ ФОРМУВАННЯ МІЖКУЛЬТУРНОЇ КОМПЕТЕНТНОСТІ КУРСАНТІВ ВИЩИХ ВІЙСЬКОВИХ НАВЧАЛЬНИХ ЗАКЛАДІВ
}

\begin{abstract}
У статті розглянуто сутність поняття «мотивачія» та визначено роль мотивачії вивчення іноземної мови військовослужбовиями для формування міжкультурної компетентності. 3'ясовано умови, за яких відбувається підвищення рівня вмотивованості курсантів ВВНЗ у подальшому професійному зростанні та підвищенні продуктивності прачі для вирішення службових задач. Обгрунтовано значення та вплив гуманітарного складника підготовки військового фахівия на коло ключових, загально-галузевих та предметних компетентностей, необхідність організації ефективної програми становлення військового фахівия шляхом безперервної освіти. У статті визначено поняття «позитивна мотивація» як сукупність факторів, які допоможуть військовослужбовцям Збройних Сил Украӥни успішно вивчати мови, бути здатними розуміти інформацію іноземними мовами, а також спілкуватися та практикувати мовленнєві моделі в різних ситуаџіях повсякденної та професійної діяльності. Інша сторона позитивної мотивації передбачає здатність курсантів до самооиінки та самопідготовки, щзо може спонукати військовослужбовців до професійного вдосконалення иляхом безперервної освіти. У статті подаються результати попередніх наукових досліджень для підтвердження значення позитивної мотивачї як основного елементу в прочесі вдосконалення міжкультурної компетентності для військовослужбовців. Сучасні процеси та нововведення у Збройних Силах Украйни та вимоги до військовослужбовців, щчо стрімко зростають у ході інтеграиії до Свропейського співтовариства та НАТО, свідчать про необхідність у позитивній мотивачіі до активного навчання, щзоб забезпечити готовність висококваліфікованого українського військовослужбовия вирішувати професійні завдання, послуговуючись міжкультурною компетентністю.
\end{abstract}

Ключові слова: мотивація, міжкультурна компетентність, гуманітарний складник, фахова комунікація, навчальні мотиви.

Nataliia NECHYPORUK, orcid.org/0000-0002-6770-813X Associate Professor at the Department of Foreign Languages Korolov Zhytomyr Military Institute (Zhytomyr, Ukraine) Natanechyporuk@ukr.net

\section{THE ROLEOFMOTIVATIONINTHE PROCESS OFFORMINGTHE INTERCULTURAL COMPETENCE OF HIGHER MILITARY EDUCATIONAL INSTITUTIONS}

The article deals with the essence of the concept of "motivation" and defines the role of motivation of studying a foreign language by military personnel for the formation of intercultural competence. The conditions to foster the level of motivation of military students of higher educational establishments in the further professional development and the level of labor productivity for the solving of service tasks are found out. The importance and impact of the humanitarian component of military specialist training on the range of key, general-sectoral and subject competences, the necessity of organizing an effective program of becoming a military specialist through continuing education are substantiated. The article defines the concept of "positive motivation" as a set of factors that would help the servicemen of Ukrainian Armed Forces to be good language learners, capable to comprehend information in foreign languages as well as communicate and practice speech patterns in various situations of everyday and professional activities. Another side of positive motivation includes the ability of military students for self-evaluation and self-study which may motivate servicemen to professional improvement by means of life long education. The article illustrates the results of previous scientific research to provide the significance of positive motivation as a core element in the process of intercultural competence enhancement for military personnel. Current processes and innovations in the Armed Forces of Ukraine and proliferating requirements to the military personnel in the course of integration to European community and NATO show the urgency of positive motivation to be actively nurtured to assure the readiness of a highly qualified Ukrainian serviceman to solve professional tasks using intercultural competence.

Key words: motivation, intercultural competence, humanitarian component, professional communication, educational motives. 
Постановка проблеми. На сучасні процеси модернізації освітнього процесу впливають внутрішні та зовнішні чинники: передусім це загальнонаціональні інтереси і державні пріоритети, а також світові тенденції і ноу-хау в освітніх технологіях. У процесі підготовки військових фахівців здійснюється не лише комунікативний вплив на слухача, а й забезпечується професійна соціалізація: формування особистісних якостей курсанта, розвиток його індивідуальних особливостей, опанування ним знань специфічних технологій зі спеціальності, які в майбутньому стануть засобом і змістом його професійної діяльності. Надалі це може гарантувати розвиток інтелектуально-творчого потенціалу особистості фахівця. Залишаючись у статусі стандартних учасників суб'єкт-суб'єктної вербальної взаємодії, основним завданням викладача під час такої взаємодії $\epsilon$ створення сприятливих умов для формування міжкультурної компетентності як одного зі складників професійного становлення майбутнього фахівця у військовій сфері. Однак натепер існують протиріччя між способом викладання навчального матеріалу і ступенем засвоєння його учасниками освітнього процесу через низьку мотивацію до опанування іноземної мови як провідного засобу формування міжкультурної компетентності. Тому існує необхідність аналізу умов, а також засобів і способів підвищення вмотивованості вивчення іноземних мов, аби запобігти пасивному засвоєнню знань, що в результаті призведе до зниження продуктивності освітнього процесу загалом та зменшення показників якості навчання зокрема. Так, вивчення іноземної мови у вищих військових навчальних закладах зводиться до пояснення навчального матеріалу, виконання практичних завдань для подальшої перевірки рівня сформованості мовленнєвих компетенцій, тоді як курсант не розуміє сферу їх застосування в майбутній професійній діяльності. Наприклад, для мовлення військових характерним $є$ вживання мовних кліше та лексичних єдностей, що значно ускладнює процес вивчення іноземної мови через труднощі перекладу таких одиниць мови. У такому випадку можемо простежувати відсутність мотивації до заучування тих чи інших лексичних структур, хоча саме завдяки цьому мовлення стає цілісним $\mathrm{i}$ зв'язним. Такі характеристики мовлення допоможуть військовослужбовцю оперативно налагоджувати мовні контакти з метою отримання інформації та формулювати тексти рапортів та доповідей, дотримуючись лаконічності та чіткості викладу думок. Інший чинник, що впливає на мотивацію до вивчення іноземної мови, - це відсутність розуміння екстралінгвістичних знань, що формуються за алгоритмом: знання теми дає знання культури, що випливає зі знання контексту, що у свою чергу дає соціокультурні знання, які є основою формування міжкультурної компетентності.

Аналіз досліджень. Сучасні теоретичні дослідження вчених у галузі мотивації та стимулювання базуються на працях багатьох вітчизняних науковців, а саме: А. Афоніна, Д. Богині, Е. Уткіна, Л. Владімірової, Н. Лозінської, О. Ромашова та інших. Так, А. Афонін визначає мотивацію як процес стимулювання окремої людини або групи людей до діяльності, спрямованої на досягнення цілей організації (Афонін, 2008: 7). Д. Богиня підкреслює суб'єктивну сторону мотивації, що випливає із потреб, бажань, почуттів та інтересів людини (Богиня, 2003: 13). Н. Лозінська зазначає про існування певної залежності ефективності професійної діяльності від мотивації: чим вищий ступінь сформованості позитивної мотивації, тим вища результативність діяльності (Лозінська, 2012: 227).

Дослідженням процесу мотивації курсантів, офіцерів, військовослужбовців строкової служби присвятили свої роботи українські військові педагоги і психологи М. Варія, Г. Гайдукевич, Г. Гребенюк, М. Дорошенко, М. Корольчук, І. Ліпатов, Є. Потапчук, І. Приходько, О. Сафін, М. Томчук, В. Ягупов та ін. Проблему мотивації до військової служби розкрито в працях О. Гринчишиної, Ю. Шеремети, О. Шестопалової та ін. Питанням мотивації до підвищення ефективності професійної діяльності присвятили свої роботи Л. Кален, К. Кальницька, Д. Кобзін, А. Москаленко, С. Москвичов, А. Стародубцев та ін.

Мета статті - 3'ясувати сутність поняття «мотивація» та визначити його роль у процесі вивчення іноземної мови військовослужбовцями для формування міжкультурної компетентності, проаналізувати значення гуманітарного складника загалом та процесу комунікації як засобу формування професійних компетентностей військового фахівця.

Виклад основного матеріалу. Невпинні процеси інформатизації та глобалізації системи освіти і науки диктують нові вимоги перед військовими фахівцями. Перед випускником військового закладу вищої освіти (далі - ВЗВО) постає завдання засвоєння повного циклу навчальних дисциплін, як спеціальних, так і гуманітарних. Незважаючи на технічну чи військово-спеціальну спеціалізацію, гуманітарний складник $\epsilon$ не лише обов'язковим, але й необхідним засобом вирішення професійних завдань. Адже будь- 
який фахівець залишається елементом соціуму, що оперує набутими компетенціями отримання, обробки, збереження і практичного застосування інформації, вербальної взаємодії з іншими реципієнтами певної професійної групи. Формування міжкультурної компетентності у військовослужбовців передбачає володіння всіма вищезазначеними компетенціями, що насамперед пов'язано 3 процесом спілкування. Відповідно до комунікативної ситуації та аудиторії, на яку націлений інформаційний вплив, учасник діалогу підбирає вербальні та невербальні засоби спілкування. Так, спілкуючись із однокурсниками під час перерви, він вибирає фамільярний стиль спілкування, уникаючи кліше під час звертання, вживаючи скорочення, активно послуговуючись жестами та мімікою. Під час навчання курсант надає перевагу нейтральному стилю, що так само позначиться на формулах звертання, називаючи однокурсників за ім'ям та помірно вживаючи невербальні засоби мовлення. Іншої поведінки вимагатиме офіційний стиль спілкування, що стає в нагоді під час наукових конференцій, нарад, семінарів та навчань, де особливо важливим $є$ дотримання встановлених норм. Під час вивчення навчальних дисциплін гуманітарного циклу, зокрема іноземної мови, досить важливим для курсанта стає розуміння того, наскільки ті чи інші засоби мови доречно вживати в кожному зі стилів. У контексті міжкультурної компетентності будемо говорити про участь курсантів у міжнародних заходах із залученням експертів зі США та країн Свропи, під час яких основною мовою спілкування $\epsilon$ англійська. Саме в таких ситуаціях курсанту необхідно володіти рядом компетенцій, що допоможуть йому бути повноцінним учасником комунікації та усвідомити цінність уже набутих умінь та пріоритетів, до яких слід прагнути.

Як зазначають Ю. Зіньковський і Г. Мірських, випускнику недостатньо володіти системою знань, має бути розуміння, як і де застосувати ці знання. Автори виділяють два складники професійної компетентності: з одного боку, це система знань, набутих під час вивчення циклу фундаментальних та спеціальних дисциплін, з іншого - це вміння користуватися ними для вирішення професійних задач (Зіньковський, Мірських, 2009: 131). Згідно $з$ вимогами до компетентностей військового фахівця, окрім технічних і технологічних аспектів, від випускника вимагатимуть комунікативних та організаторських умінь, що $є$ прерогативою гуманітарного складника професійної підготовки, навчаючи професійно орієнтованій комунікації, спрямованій на конкретного адресата - фахівця певної військової спеціалізації.
Лінгвістичний складник гуманітарного циклу забезпечує формування професійно спрямованої міжкультурної комунікативної компетентності майбутніх фахівців, створення мовно-мовленнєвої бази, оперуючи якою, можна реалізувати будь-яку ситуацію мовного спілкування в професійній сфері. Ключовим поняттям у даному процесі $\epsilon$ комунікація. Феномен комунікації вже довгий час є об'єктом дослідження соціології, філософії, політології, психології, лінгвістики, культурології тощо. Комунікація сьогодні $\epsilon$ одним 3 основних засобів отримання оновлених знань та умінь. Так, результатом міжособистісної комунікації стає не лише факт отримання даних, але $\mathrm{i}$ їх сучасна та адекватна інтерпретація. Ураховуються як ключові компетентності отримання інформації через навчальну діяльність, так i загальногалузеві компетентності, такі як міжкультурна, основою якої $є$ процес комунікації. Випускники ВЗВО - спеціалісти з галузей знань, що стрімко розвиваються, такі як технології програмування, IT-технології чи захист інформації, не завжди знайдуть актуальну інформацію в підручниках чи інтернет-джерелах. Вони повинні оперувати міжкультурною компетентністю для отримання знань із першоджерел, а саме таких, як: консультації з повідними фахівцями в галузі, онлайн-участь у тренінгах, відеоконференціях, семінарах, експрес-аналіз джерел ЗМІ тощо.

Програма підготовки військових фахівців передбачає такі складники: політична та ідеологічна підготовка; професійна підготовка; країнознавча та мовна підготовка. Останній складник програми підготовки показує, що вимоги до сучасних фахівців не обмежуються професійною компетентністю - важливою $є$ підготовка до міжкультурних комунікацій шляхом оволодіння іноземними мовами, зокрема англійською, як мовою стратегічного спрямування в межах зростання співпраці з НАТО. Аналіз діяльності військовослужбовців, пов' язаної з контактами представників різних культур у процесі вирішення стратегічних професійних завдань під час ділових переговорів, дипломатичної підтримки представників країнпартнерів у сфері військової справи, міжнародних наукових конференцій, презентацій, спеціалізованих виставок, дає можливість стверджувати про актуальність і необхідність формування міжкультурної компетентності фахівців військової галузі (Нечипорук, 2018: 86). Перед військовими відкриваються можливості безпосередньої взаємодії 3 носіями мови, що служить засобом отримання інформації $з$ першоджерела та дозволяє далі оперативно і якісно вирішувати поставлені професійні задачі. Через це зростає значення компетент- 
нісного підходу в освітньому процесі. Як зазначає В. Ковальчук, компетентнісний підхід зорієнтований на практичні результати, досвід особистої діяльності, вироблення ставлень, що зумовлює принципові зміни в організації навчання, яке стає спрямованим на розвиток специфічних цінностей і професійно значущих знань і умінь студентів (Ковальчук, 2016: 62).

Для досягнення необхідного рівня формування міжкультурної компетентності до уваги береться фактор мотивації вивчення іноземної мови. На це вказує той факт, що сучасний фахівець, отримавши повну вищу освіту, а саме науковий ступінь бакалавра та магістра, повинен бути й надалі вмотивованим до подальшого і постійного розширення і оновлення науково-теоретичної бази та набору вмінь і навичок, що забезпечить його продуктивність і конкурентоспроможність на ринку праці. Тому для військовослужбовців пріоритетним має стати процес безперервної освіти або освіти потягом життя (Lifelong education). Такі тенденції відповідають упровадженню програм міжнародної взаємодії в галузі військової освіти за сприяння Міністерства оборони США та НАТО, що реалізуються Міністерством оборони України та Бюро міжнародної мовної координації НАТО (BILC) щодо проходження та вдосконалення військовослужбовцями Збройних сил України фахової підготовки та поширення практики мовної підготовки, а саме: Defence Education Enhancement Program (DEEP), International Military Education and Training (IMET) program та Bilateral Militaryto-Military program (Mil-Mil). Для того щоб випускники ВЗВО усвідомлювали важливість таких тенденцій, потрібно створювати умови для підвищення мотивації до вивчення іноземних мов у курсантів молодших курсів у зв'язку 3 тим, що процес формування позитивної мотивації повинен бути тривалим, систематичним та продуктивним.

Оскільки концепт «мотивація» $є$ базовим в організації навчального процесу та формуванні компетентностей, слід розглянути його з позицій різних галузей науки.

У психології увага приділяється здебільшого поняттю мотивів, як рушійних сил, що спонукають людину до певного роду діяльності для отримання результатів. На думку психологів, наявність самих лише мотивів не завжди призводить до результату, прагненням людини досягти поставлених цілей допомагає наполегливість (Маслов, 2005: 55). С. Занюк характеризує мотивацію як сукупність спонукальних факторів, що визначають активність організму і його спрямованість (Занюк, 2008: 5).
А. Калініченко розглядає поняття «мотивація» як багатогранне соціально-економічне явище, яке поєднує різні концепції: це сукупність об'єктивних і суб' єктивних факторів; стан особи; внутрішні та зовнішні рушійні сили; процес спонукання; управлінська діяльність; сукупність мотивів тощо. Узагальнення наведених визначень дозволяє зробити висновок, що мотивація являє собою сукупність внутрішніх і зовнішніх рушійних сил, що спонукають людину до діяльності, визначають тип іiї поведінки, орієнтують на досягнення поставлених цілей (Калініченко, 2013: 417).

У менеджменті поняття мотивації розглядається як засіб впливу на працівника 3 метою покращення продуктивності праці і збільшення прибутковості (Бондар, 2010: 176).

У педагогічній літературі мотивація служить одним із компонентів формування професійної компетентності. Мотиваційний компонент передбачає формування позитивної мотивації до вибору професії, результатів навчальної діяльності для формування ціннісних орієнтацій, осмислення ролі компетентного фахівця в обраній галузі та для добробуту суспільства і нації, а також для формування власного бачення професійного вдосконалення і зростання (Ковальчук, 2016: 167).

Формування мотивації - це динамічний процес, що характеризується впливом на поведінку людини і відбувається в кілька етапів. Так, на початкових етапах виникає власне потреба в певній діяльності та пошуку способів задоволення такої потреби. У нашому випадку курсант відчуває потребу в підвищенні рівня володіння іноземною мовою через неспроможність виконання певних мовленнєвих завдань. Це сприяє виникненню стимулів до пошуку способів покращення мовленнєвих навичок. Наступний етап вимагає пошуку й визначення цілей, напрямів дій та здійснення конкретних кроків у досягненні поставлених задач (Калініченко, 2013: 417). На цьому етапі до освітнього процесу долучається педагог, що володіє необхідною методологічною базою, для вибору дієвих методів 3 урахуванням індивідуального підходу. Таким чином, викладач підбирає задачі, які курсант здатен виконати на даному етапі, аби стимулювати й сформувати позитивну мотивацію для досягнення кінцевої мети. Цей процес має враховувати поступовість у формулюванні цілей, аби досягти бажаних результатів. Оскільки мотивація в психолого-педагогічній літературі розглядається не лише як сукупність мотивів, а і як процес узгодження їх із мотивуючою ситуацією (Музика, 1999: 152), то основна задача педагога - з'ясувати, які мотиви навчаль- 
ної діяльності особистості стануть формантами мотивації до вивчення іноземної мови.

Серед навчальних мотивів соціальні переважають над пізнавальними. Пізнавальні пов'язані зі змістом навчальної діяльності та процесом iï здійснення, тоді як соціальні мотиви передбачають взаємодію курсантів з іншими людьми. Шляхами реалізації соціальних мотивів $є$ залучення курсантів ВЗВО до перекладацької діяльності під час візитів членів міжнародних делегацій з країнучасників НАТО. У такій взаємодії можемо спостерігати інтеграцію навчального процесу і міжкультурної комунікації. У процесі спілкування 3 носіями мови курсанти набувають ряд важливих компетенцій, які не завжди вдається набути під час аудиторних занять у навчальному закладі. Серед найбільш важливих компетенцій для формування їх у військовослужбовців у процесі іншомовної підготовки ми виділяємо такі: здатність до співпраці, взаєморозуміння через комунікацію, здатність подолання мовного бар'єру, винахідливість та креативність, а також потенційні здібності, що реалізуються в умовах спонтанності мовлення та виведення із зони комфорту за умови нестандартності ситуацій спілкування, застосування вмінь оперувати набутими знаннями на практиці.

Для формування міжкультурної компетентності важливим $є$ рівень внутрішньої мотивації, зорієнтованої на процес і результат, що інтегрується із зовнішньою, як можливістю отримати успіх, досягнення, нагороду, заохочення чи авторитет, і призводить до підвищення загальної вмотивованості стати висококваліфікованим фахівцем у військовій справі, готовим до вирішення завдань на оперативно-стратегічному рівні.

3 цією метою нами було проведено опитування курсантів Житомирського військового інституту імені С. П. Корольова методом анкетування для визначення рівня сформованості позитивної мотивації до вивчення іноземної мови як засобу професійного становлення військовослужбовця. В опитуванні взяли участь курсанти 1-3-х курсів. Кількість респондентів становила 75 учасників, яким було запропоновано розподілити бали від 1 до 7 за ступенем важливості вивчення іноземної мови, де 1 - найменш важливий критерій, 7 - найбільш важливий. В анкеті нами було сформульовано 7 критеріїв. За результатами опитування 40\% учасників вибрали найбільш важливим критерієм можливість отримати фінансову стабільність; $30 \%$ - прагнення до просування по службі; $7 \%$ можливість закордонних відряджень; 6\% - прагнення уникнути критики та догани з боку керівництва, колег, сім'ї; 2\% - потреба в досягненні соціального престижу й поваги 3 боку інших; 7\% - можливість підвищити самооцінку та самореалізуватися у військовій службі; 8\% - фактор, що впливає на поточну успішність. Аналіз результатів опитування показав, що у більшості опитаних зовнішня позитивна мотивація переважає над внутрішньою. Цей факт вказує на зростання престижності військової професії, але нагальною потребою є пошук методів підвищення внутрішньої мотивації як передумови індивідуального і професійного зростання та формування всесторонньо розвиненої особистості, щоб дати змогу курсантам усвідомити необхідність і важливість формування у них міжкультурної компетентності як невід'ємної складової частини професійної компетентності.

Висновки. Отже, нами зроблено спробу розглянути сутність поняття «мотивація» та визначити значення мотивації в процесі вивчення іноземної мови військовослужбовцями для формування міжкультурної компетентності. 3'ясовано умови та шляхи реалізації, за яких можливе підвищення рівня вмотивованості курсантів вищих військових навчальних закладів, таких як занурення в іншомовне середовище для стимулювання розвитку навичок спонтанного мовлення, що $є$ необхідною передумовою формування всебічно розвиненої особистості та висококваліфікованого фахівця. Адже потреба в таких спеціалістах є нагальною для Збройних Сил України на сучасному етапі євроінтеграції та співпраці з НАТО.

Оскільки знання англійської мови стає пріоритетним напрямом розвитку Збройних Сил України, перед сучасним військовим фахівцем ставиться ряд вимог, одна 3 яких - формування професійно спрямованої міжкультурної компетентності. Таким чином, курсант, що володіє певним понятійно-термінологічним апаратом за своєю спеціалізацією, має можливість перевірити власні знання та вміння, провести самоаналіз рівня сформованості як міжкультурної, так і предметних компетентностей, а також отримати об'єктивні відгуки від іноземних фахівців щодо готовності до професійної діяльності.

Професійна підготовка майбутніх військовослужбовців здійснюється як комплексний педагогічний вплив, метою якого $€$ формування ряду компетентностей, серед яких пріоритетною на даний час вважається міжкультурна компетентність. За результатами проведеного нами опитування було з'ясовано, що курсанти мають недостатньо сформований рівень внутрішньої позитивної мотивації до вивчення іноземної мови, що стане предметом наступних наукових розвідок. 


\section{СПИСОК ВИКОРИСТАНИХ ДЖЕРЕЛ}

1. Афонин А. С. Основы мотивации труда : Организационно-экономические аспекты : учеб. пособие. Киев : Укр. энциклоп. им. М. П. Бажана, 2008. 304 с.

2. Богиня Д. П. Ментальний чинник у сфері праці : проблеми теорії та практики : монографія. Київ : Шторм, 2003. $382 \mathrm{c}$.

3. Бондар В. Д. Еволюція мотивації як функції управління. Наукові записки. Сер. Культура та соціальні комунікаųiі / за заг. ред. канд. філос. наук, доц. Л. В. Квасюк. Острог : Видавництво Національного університету «Острозька академія», 2010. Вип. 2. С. 175-185.

4. Занюк С. С. Психологія мотивації та емоцій : навч. посіб. для студ. гуманіт. факультетів ВНЗ. Луцьк : РВВ Волин. держ. ун-ту ім. Лесі Українки, 2008. 180 с.

5. Зіньковський Ю. Ф., Мірських Г. О. Компетентність випускника - критерій якості технічної освіти. Вісник Національного технічного університету України «КПІ». Сер. Радіотехніка. Радіоапаратобудування. 2009. Вип. 39. C. $131-138$.

6. Калініченко А. В. Мотивація та мотиваційний процес : сутність та поняття. Вісник економіки транспорту і промисловості. 2013. Вип. 42. С. 417-420.

7. Ковальчук В. А. Професійна підготовка майбутніх учителів до роботи в умовах варіативності освітньо-виховних систем : теорія, методика, практика : монографія. Житомир : Вид-во ЖДУ ім. І. Я. Франка, 2016. 442 с.

8. Лозінська Н. С. Особливості мотивації до професійної діяльності військовослужбовців миротворчих підрозділів. Вісник Національного університету оборони України. 2012. Вип. 5 (30). С. 227-231.

9. Маслов А. О. Основи психології та педагогіки : навч. посіб. Житомир : ЖДТУ, 2005. С. 54-61.

10. Музика О. О. Теоретичні та методологічні проблеми дослідження мотивації творчості. Вісник Житомир. держ. ун-ту ім. I. Франка. 1999. Вип. 3. С. 151-155.

11. Нечипорук Н. Л. Теоретичні засади формування міжкультурної компетентності курсантів вищих військових навчальних закладів. Проблеми освіти : збірних наукових працьь. ДНУ «Інститут модернізації змісту освіти» МОН України. Вінниця : ТОВ «Нілан - ЛТД», 2018. Вип. 88. Ч. 2. С. 83-91.

\section{REFERENCES}

1. Afonin, A. S. (2008). Osnovy motivatsyi truda: Orhanizatsyonno-ekonomicheskie aspekty [Fundamentals of work motivation: Organizational and economic aspects]. Kyev: Ukr. entsyklop. im. M. P. Bazhana [in Russian].

2. Bohynia, D. P. (2003). Mentalnyi chynnyk u sferi pratsi: problemy teorii ta praktyky [Mental factor in labor: problems of theory and practice]. Kyiv: Shtorm [in Ukrainian].

3. Bondar, V. D. (2010). Evoliutsiia motyvatsii yak funktsii upravlinnia [The evolution of motivation as management functions]. Ostrog: Vydavnytstvo Natsionalnoho universytetu «Ostrozka akademiia» [in Ukrainian].

4. Zaniuk, S. S. (2008). Psykholohiia motyvatsii ta emotsii [Psychology of motivation and emotion]. Lutsk: RVV Volyn. State University named after Lesia Ukrainka [in Ukrainian].

5. Zinkovskyi, YU. F., Mirskykh H. O. (2009). Kompetentnist vypusknyka - kryterii yakosti tekhnichnoi osvity [Graduate's competence - a criterion for the quality of technical education]. Kyiv: Visnyk of National Technical University of Ukraine «KPI» [in Ukrainian].

6. Kalinichenko, A. V. (2013). Motyvatsiia ta motyvatsiinyi protses: sutnist ta poniattia [Motivation and motivation process: essence and concept]. Kyiv: Visnyk ekonomiky transportu i promyslovosti [in Ukrainian].

7. Kovalchuk, V. A. (2016). Profesiina pidhotovka maibutnikh uchyteliv do roboty v umovakh variatyvnosti osvitno-vykhovnykh system: teoriia, metodyka, praktyka [Professional training of future teachers to work in the conditions of variability of educational systems: theory, methodology, practice]. Zhytomyr: Ivan Franko Zhytomyr State University [in Ukrainian].

8. Lozinska, N. S. (2012). Osoblyvosti motyvatsii do profesiinoi diialnosti viiskovosluzhbovtsiv myrotvorchykh pidrozdiliv [Features of motivation for professional activity of military peacekeepers]. Kyiv: Visnyk Natsionalnoho universytetu oborony Ukrainy [in Ukrainian].

9. Maslov, A. O. (2005). Osnovy psykholohii ta pedahohiky [Fundamentals of Psychology and Pedagogy]. Zhytomyr : ZHDTU [in Ukrainian].

10. Muzyka, O. O. (1999). Teoretychni ta metodolohichni problem doslidzhennia motyvatsii tvorchosti [The theoretical and methodological issues of creativity motivation research]. Zhytomyr : ZHDTU [in Ukrainian].

11. Nechyporuk, N. L. (2018). Teoretychni zasady formuvannya mizhkulturnoi kompetentnosti kursantiv vyshchykh viiskovykh navchalnykh zakladiv [Theoretical bases of formation of intercultural competence of cadets of higher military educational establishments]. Vinnytsya : TOV «Nilan - LTD» [in Ukrainian]. 